\title{
The Scandinavian Caledonides-Scientific Drilling at Mid-Crustal Level in a Palaeozoic Major Collisional Orogen
}

by Henning Lorenz, David Gee, and Christopher Juhlin

doi:10.2204/iodp.sd.11.10.2011

\section{Introduction}

The Caledonides of western Scandinavia and eastern Greenland have long been recognized to have been part of a collisional orogen of Alpine-Himalayan dimensions, essentially the result of the closure of the Iapetus Ocean during the Ordovician, with development of island-arc systems, and subsequent underthrusting of continent Laurentia by Baltica in the Silurian and Early Devonian during Scandian collisional orogeny. Several hundreds of kilometers of thrust

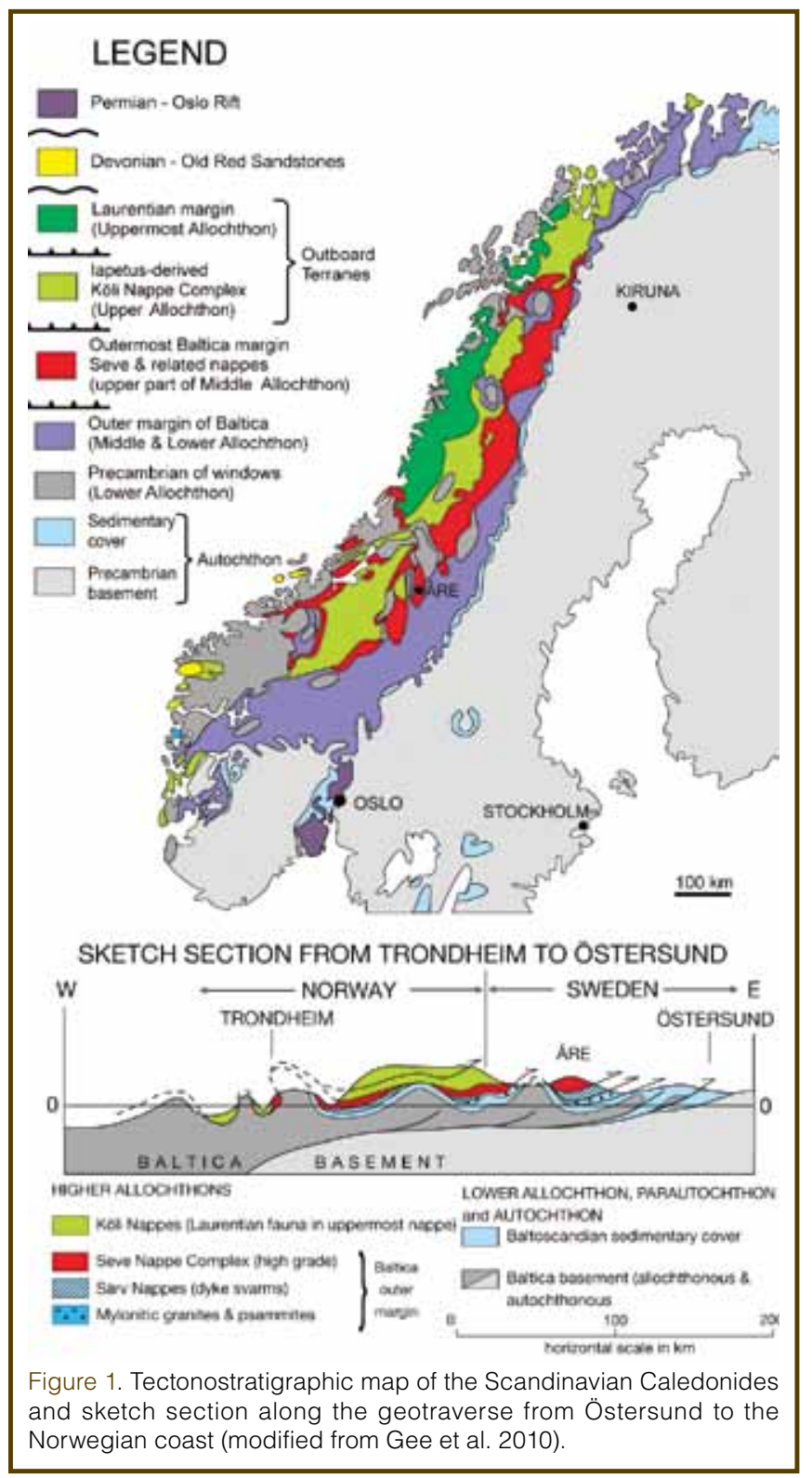

emplacement of allochthons have been demonstrated, E-directed in the Scandes and W-directed in Greenland.

In Scandinavia, major allochthons (Fig. 1) were derived from Baltica's outer shelf, dyke-intruded continent-ocean transition zone (COT), Iapetus oceanic domains and (uppermost) from the Laurentian margin. On the western side of the North Atlantic, exposed along the eastern edge of the Greenland ice cap, there are major thrust sheets, all derived from the Laurentian continental margin and transported at least two hundred kilometers westwards onto the platform. In the Scandinavian and Greenland Caledonides, the major allochthons that were derived from the outer parts of the continent margins have been subject to high-grade metamorphism and apparently were emplaced hot onto the adjacent platforms.

The International Continental Scientific Drilling Program (ICDP) workshop in Sweden provided an opportunity to examine the evidence for Caledonian collisional orogeny in Scandinavia and to discuss its relevance for understanding other orogens, particularly Himalaya-Tibet, and also the subduction systems along the margin of the western Pacific. The Scandinavian Caledonides are one of the best places on the planet to study the emplacement not only of highly ductile allochthons generated in an outer continental margin subduction complex, but also of associated hot (granulite facies paragneisses with leucogranites) extruding nappes that were the potential heat source for the metamorphism of underlying and overlying long-transported allochthons.

\section{cosc Project Rationale}

The Collisional Orogeny in the Scandinavian Caledonides (COSC) project focuses on the transport and emplacement of subduction-related high-grade COT assemblages (the Seve Nappe Complex) onto the Baltoscandian platform and their influence on the underlying allochthons and basement. Research will be performed by an international working group with experience from studying fossil and active mountain belts. Orogenic processes and their development over time will be investigated by scientific drilling in the deeply eroded (mid-crustal levels) Scandinavian Caledonides, and the results will be compared from this unique locality with a modern analogue of similar size, the Himalaya-Tibet mountain belt, and the arc collisional systems between the Eurasian and Pacific plates. 


\section{The Workshop}

The workshop was attended by about sixty participantshalf from outside of the Nordic countries-on 21-25 June 2010 in Åre, Sweden, close to the planned drilling sites. The workshop was divided into two parts, separated by a full day's excursion on 23 June (Fig. 2). The Scandinavian Caledonides, a modern analogue (the Himalaya-Tibet mountain belt), and the highly successful ICDP project in the Sulu ultra-high pressure belt (the Chinese Continental Scientific Drilling Program) were presented on the first day. Presentations on the emplacement of hot allochthons were made on the second day, followed by geological and geophysical workshop sessions on orogen-scale processes. The afternoon session focused on the Scandian hinterland, before taking a rapid ascent to the "hot allochthon" on cold and snowy Åreskutan mountain. Evening lectures provided introductions to ICDP and the Swedish Deep Drilling Program, in particular the purchase of a mobile drilling rig capable of coring down to depths of at least $2.5 \mathrm{~km}$. The mid-workshop excursion concentrated on the rock units (excluding the unknown basement) through which we plan to drill, from the amphibolite facies Seve Nappe Complex to underlying greenschist facies metasedimentary units of the Middle Allochthon and Cambro-Silurian Lower Allochthon. On the fourth day, lectures were held about drillhole-related geophysics and western Pacific subduction systems, particularly the Izu-Bonin-Mariana Arc; workshop sessions covered details of the science related to the drillholes and drill cores; and general discussion of COSC science was conducted. The day ended with presentations on the hydrological and geothermal aspects of the Scandian mountain belt and drilling program. The last morning of the workshop was spent winding up the COSC science plan and defining a road map for the coming six months, with preparation of a comprehen-
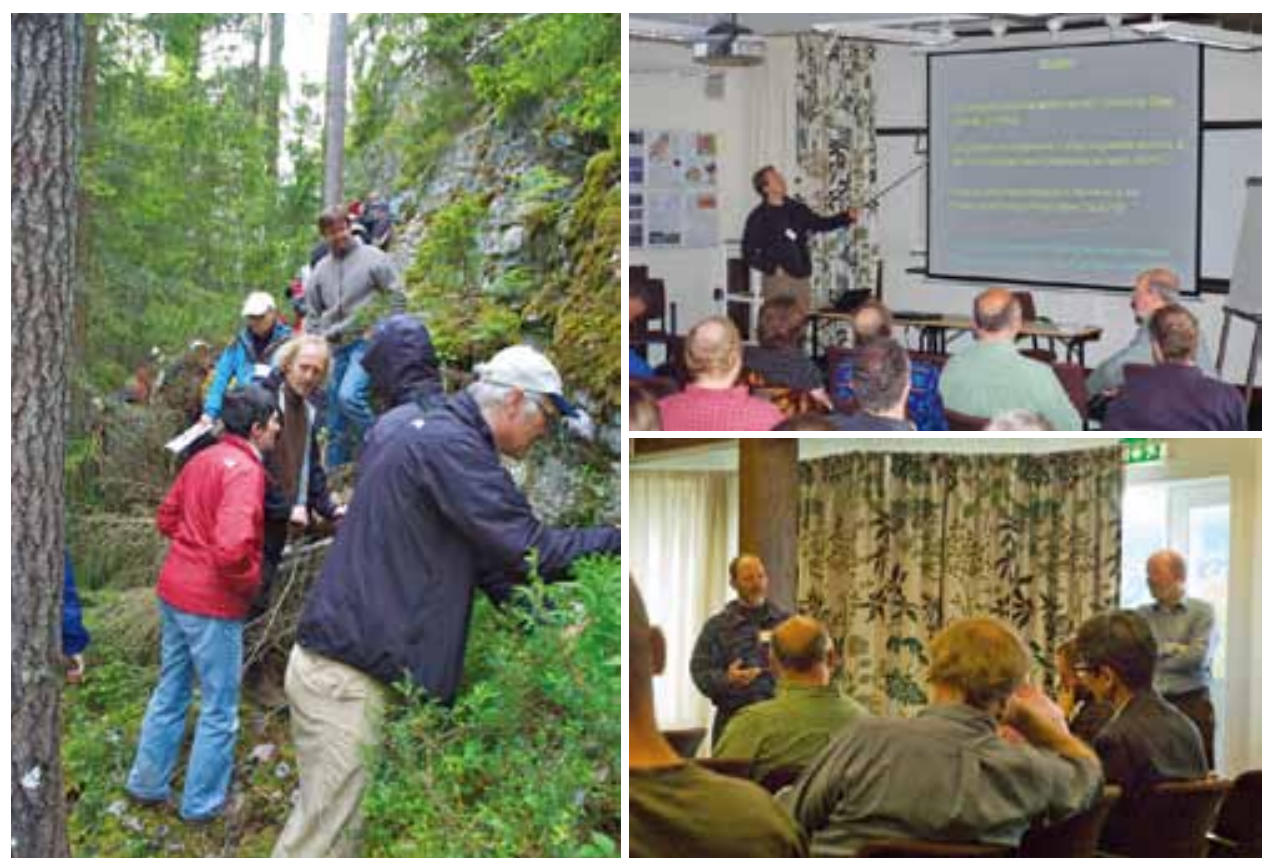

Figure 2. Scenes from the COSC science workshop presentations, discussions, and excursions Participants on one of the key localities of the lower, poorly exposed tectonostratigraphic units. sive drilling proposal to ICDP and applications to funding agencies.

\section{COSC Drilling Program}

Two drillholes, each $\sim 2.5 \mathrm{~km}$ deep, are planned to core a composite profile from the "hot" Seve nappes downwards, through the underlying lower grade allochthons, into the Fennoscandian basement. They are located near the towns of Åre and Järpen (Fig. 3).

The geology of the Åre area is renowned for classical studies of vast overthrusting (Törnebohm, 1888), with high-grade metamorphic rocks (granulite facies) on the top of Åreskutan mountain emplaced over Cambro-Silurian sedimentary rocks in the valley below. Drilling will start in the lower part of the well-exposed section and continue through less exposed amphibolite and greenschist facies units in the underlying nappes. The second hole, near Järpen, will continue the section through the underlying autochthonous cover and deep into the Fennoscandian basement.

The high spatial resolution provided by continuous drillcore will allow a detailed study of the metamorphism and its changes through and across tectonic contacts, from the high-grade allochthons into the underlying less metamorphosed nappes and basement. Oriented drillcore will serve as a basis for understanding deformation and thrust emplacement, as well as heat transport and fluid migration during metamorphism, in time and space. COSC drilling will then penetrate the lower allochthonous units and the basal décollement, most likely in Cambrian alum shale, and enter Precambrian crystalline basement. Prominent basement seismic reflectors will be studied in detail. Investigation of the apparent deformation pattern in the autochthonous basement that is observed in the seismic data will be achieved by drillcore studies and in-hole measurements. In situ and drill core investigations are also necessary to study the amount of Caledonian and older deformation and metamorphism in the basement.

Two coreholes to $\sim 2.5 \mathrm{~km}$ instead of one deep hole $(\sim 5 \mathrm{~km})$ will make the COSC project economically feasible. The second drillhole will be located further towards the foreland of the Caledonides, starting in the tectonostratigraphy just above the base of the first hole (Fig. 3). These holes will be drilled with a diamond coring drill rig to maximize core recovery and minimize costs. Both boreholes will investi- 
gate regional heat flow, water circulation patterns, the deep biosphere, and the mineral potential of the area. They will also allow calibration of high-quality surface geophysical data at depths which are not normally accessible to drilling in this tectonic environment.

\section{Working Groups}

Working groups have been established for tectonics, geophysics, geothermics, hydrogeology, and the deep biosphere. Technical operations and research will be performed by the drilling management and technology working group, utilizing the Swedish scientific drilling infrastructure.

The main objectives of the tectonics working group concern the

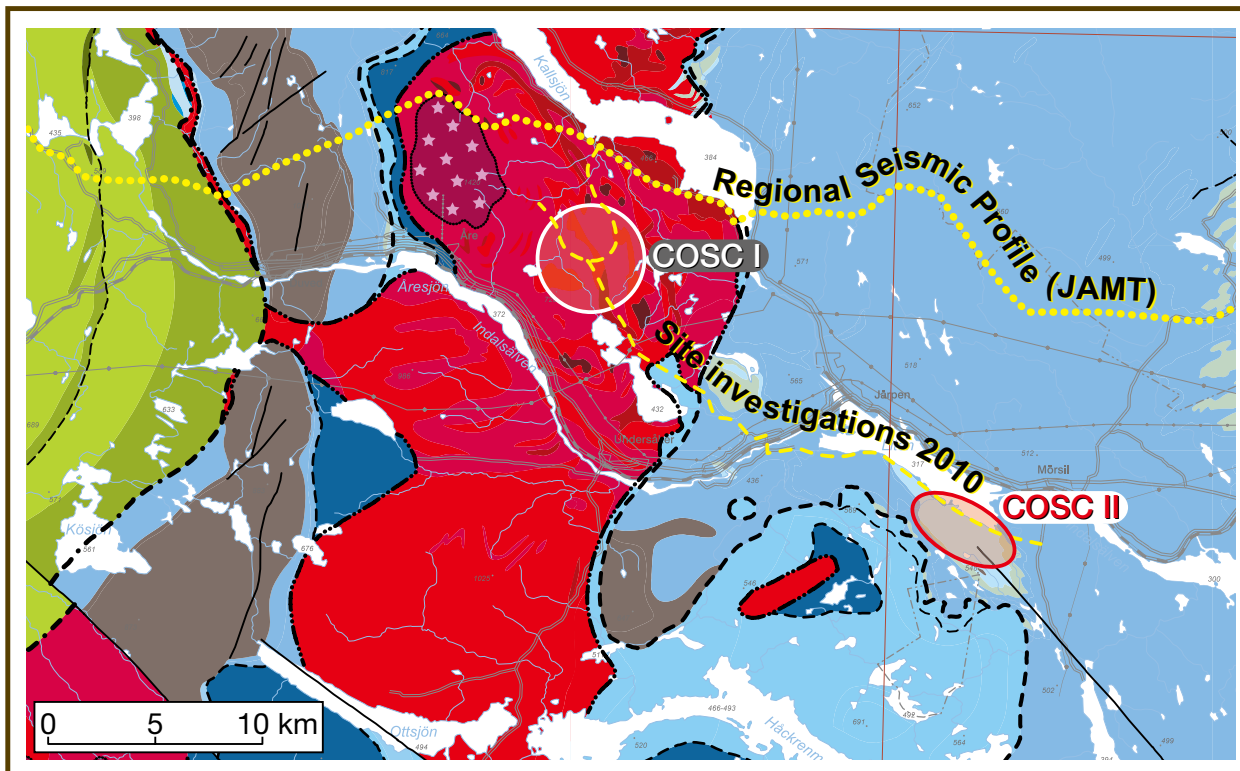

Figure 3. Geological map of the Åre-Järpen area. Marked are the areas of interest for scientific drilling (COSC I \& II), the regional seismic profile from the early 1990s (yellow dotted line, see Figure 4) and the 2010 site investigations by reflection seismics (yellow dashed line). In gray: Fennoscandian basement exposed in anticlines; in light blue: the lower-grade metamorphic Lower Allochthon; in dark blue: lower part of the Middle Allochthon; in red: the high-grade upper part of the Middle Allochthon, the Seve Nappe Complex, with highest grade rocks on the top of Areskutan mountain (stars); in green: the overlying lower metamorphic Upper Allochthon (Köli nappes).

mechanisms of emplacement of hot allochthons and the establishment a coherent model of mid-Palaeozoic (Scandian) mountain building in the North Atlantic Caledonides. Orogenic processes will be considered in ongoing and older orogens, with underthrusting of continents, doubling (even trebling) of continental thicknesses, elevation of a high plateau, partial melting of hinterland regions and ductile extrusion of allochthons many hundreds of kilometers onto adjacent platforms. In addition, new insights will be applied to the interpretation of modern analogues, in particular the Himalaya-Tibet mountain belt. The geophysics working group will map the large-scale geological structure around the boreholes and relate it to surface measurements. Cores and in-hole observations will allow determination of the origin of the observed seismic reflections during site investigations and regional seismic profiling across the mountain belt

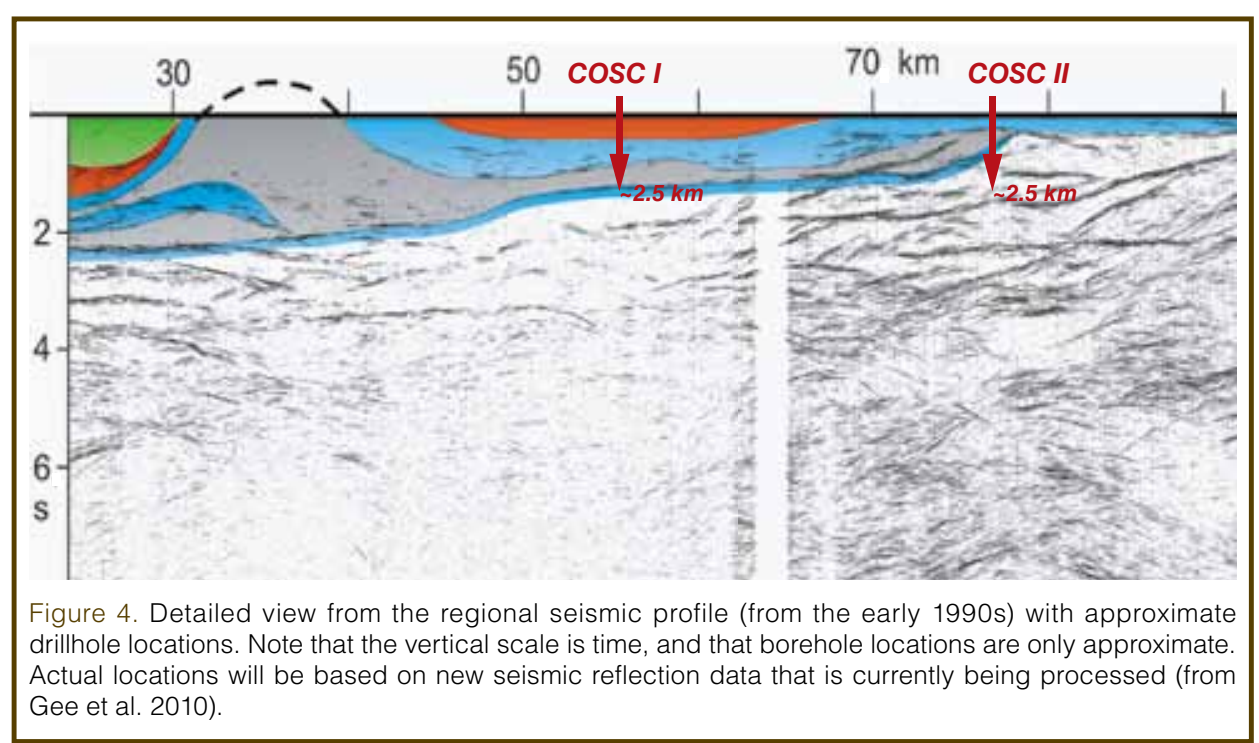

(Fig. 4). The geothermics working group focuses on assessing the heat flow and temperature in the crystalline bedrock-in the Fennoscandian Shield basement and the overlying Caledonian allochthons-and on investigating shallow boreholes $(300-400 \mathrm{~m})$ that have been drilled for mineral exploration purposes several decades ago. The hydrogeology working group will model the large-scale groundwater circulation patterns in the mountain belt and their influence on the hydrosphere of the Fennoscandian Shield basement beneath other parts of Sweden. For this purpose it is necessary to build a regional geological model which is as yet an unaddressed problem in shield areas, with importance beyond the borders of Scandinavia. The microbiology working group will investigate microbial life in highly metamorphosed sedimentary and crystalline bedrock; this study will introduce challenges different from those dealt with in sediments. Anticipated differences include distribution of biota within the rocks formations and nutrient sources to the deep biosphere, where microbial life must utilize inorganic, geological sources such as energy-rich gases.

The availability of a diamond core drill rig, recently funded by the Swedish Research Council primarily for the Swedish Deep Drilling Program, will allow the drilling management and technology working group to develop and test new drilling technologies and tools. The emphasis will be on 
enhanced sampling methods in fractured formations, data transmission while drilling, measurement while drilling, integration of true-gyro measurements while drilling, core orientation tools, and hydraulic conductivity tools.

\section{Relevance of COSC Science}

Comparison of the North Atlantic Caledonides and the Himalaya-Tibet orogen is stimulating much new research. Very different interpretations of both orogens (Soper et al., 1992; Gee et al., 2010; Streule et al., 2010) are being tested. The Caledonides in Scandinavia provide special opportunities for understanding Himalayan-type orogeny and the Himalayan Orogen itself. The last two distances comparable to those in the Scandes have seen a growing appreciation of the importance of ductile emplacement of long-transported allochthons in the Scandes and elsewhere. In particular, in the Himalayas vast lateral transport of ductile allochthons over distances exceeding those in the Scandes has been demonstrated. The Izu-Bonin-Mariana arc system, target of the ODP leg 125 (Fryer et al., 1990), takes the comparison of collisional systems a step further-to a fore-arc system where subduction, collision, thrusting, and related igneous activity and exhumation have been studied in a currently existing smaller framework.

Geological processes along active continental margins, followed by collisional tectonics and mountain building, have a profound influence on human society. Massive mountain belts like the Himalayas influence climate and weather; natural disasters are common for settlements on its steep slopes and narrow valleys. Active collisional systems are known for inflicting earthquakes on inhabitants. COSC takes a comprehensive approach to mountain building processes and their development through geological time by integrating the drilling project in the fossil orogen of the Scandinavian Caledonides with research on the Himalayas and the IzuBonin-Mariana arc collisional systems. The project will contribute to the ICDP themes "Collision Zones and Convergent Margins", "Active Faulting and Earthquake Processes” and "Climate Dynamics and Global Environments”.

After the COSC drilling project, the Jämtland transect across the Scandinavian Caledonides will be one of the best investigated profiles across a Palaeozoic mountain belt. Calibrated geophysical investigations will give insight into the structure of the shield basement and the overlying allochthons. Detailed geological studies will cover the section from the upper allochthons into the Precambrian basement (Fig. 1), including ore-bearing horizons. Intraterrestrial life, its activity, nature and origin are much less studied in crystalline bedrock than in sedimentary environments. This is also true for the hydrogeological conditions. An integrated geological-geophysical-hydrogeological model is envisaged based on new knowledge concerning the structure of the thrust sheets and the underlying basement. Results will be of importance for all kinds of underground infrastructure projects, in particular when very long-term resistance to the underground environment is central, like for waste storage. Heat flow studies will increase our knowledge about the thermal regime in the allochthons and the crystalline basement of the Fennoscandian Shield and, together with the hydrogeological results, will assess the potential for energy extraction in the Åre-Järpen region. For a more far-reaching approach, the evaluation and development of methodology to more reliably predict the geothermal gradient from shallow drill holes is important. Inversion of heat flow data will also provide valuable information about palaeotemperature. Hence, COSC will also contribute to the ICDP themes "Geobiosphere and Early Life", "Natural Resources”, and "Volcanic Systems and Thermal Regimes".

\section{References}

Fryer, P., Pearce, J.A., Stokking, L.B., et al., 1990. Proc. ODP, Init. Repts., 125: College Station, TX (Ocean Drilling Program).

Gee, D.G., Juhlin, C., Pascal, C., and Robinson, P., 2010. Collisional Orogeny in the Scandinavian Caledonides (COSC). GFF, 132:29-44.

Soper, N.J., Strachan, R.A., Holdsworth, R.E., Gayer, R.A., and Greiling, R.O., 1992. Sinistral transpression and the Silurian closure of Iapetus. J. Geol. Soc., 149:871-880.

Streule, M.J., Strachan, R.A., Searle, M.P., and Law, R.D., 2010. Comparing Tibet-Himalayan and Caledonian crustal architecture, evolution and mountain building processes. Geol. Soc. London Spec. Pub., 335:207-232.

Törnebohm, A.E., 1888. Om fjällproblemet. GFF, 10(5):328-336. (in Swedish)

\section{Authors}

Henning Lorenz, David Gee, and Christopher Juhlin, Uppsala University, Department of Earth Sciences, Villavägen 16, 75236 Uppsala, Sweden, e-mail: henning. lorenz@geo.uu.se.

\section{Related Web Links}

http://www.sddp.se/COSC

http://are-jarpen.icdp-online.org/

\section{Figure Credits}

Fig. 3: Geological map, copyright Geological Survey of Sweden (SGU). 